\title{
Towards the phylogeny of APS reductases and sirohaem sulfite reductases in sulfate-reducing and sulfur-oxidizing prokaryotes
}

\author{
Wolfgang M. Hipp, Andrea S. Pott, Natalie Thum-Schmitz, Ilka Faath, \\ Christiane Dahl and Hans G. Trüper
}

Institut für Mikrobiologie \& Biotechnologie, Rheinische FriedrichWilhelms-Universităt Bonn, Meckenheimer Allee 168, 53115 Bonn, Germany

\author{
Author for correspondence: Hans G. Trüper. Tel: +49228732320 . Fax: +49 228737576. \\ e-mail: trueper@uni-bonn.de
}

\begin{abstract}
The genes for adenosine-5'-phosphosulfate (APS) reductase, aprBA, and sirohaem sulfite reductase, dsrAB, from the sulfur-oxidizing phototrophic bacterium Chromatium vinosum strain D (DSMZ 180') were cloned and sequenced. Statistically significant sequence similarities and similar physicochemical properties suggest that the aprBA and dsrAB gene products from Chr. vinosum are true homologues of their counterparts from the sulfatereducing chemotrophic archaeon Archaeoglobus fulgidus and the sulfatereducing chemotrophic bacterium Desulfovibrio vulgaris. Evidence for the proposed duplication of a common ancestor of the dsrAB genes is provided. Phylogenetic analyses revealed a greater evolutionary distance between the enzymes from Chr. vinosum and $D$. vulgaris than between those from $A$. fulgidus and $D$. vulgaris. The data reported in this study are most consistent with the concept of common ancestral protogenotic genes both for dissimilatory sirohaem sulfite reductases and for APS reductases. The aprA gene was demonstrated to be a suitable DNA probe for the identification of apr genes from organisms of different phylogenetic positions. PCR primers and conditions for the amplification of apr homologous regions are described.
\end{abstract}

Keywords: Chromatium vinosum, adenosine-5'-phosphosulfate reductase, sirohaem sulfite reductase, phylogeny, enzyme evolution

\section{INTRODUCTION}

The utilization of sulfur compounds for energy-yielding processes seems to have developed very early during prokaryotic evolution (Skyring \& Donnelly, 1982; Wächtershäuser, 1988). Prokaryotes still play a dominant role in the oxidative and the reductive phases of the natural sulfur cycle; chemotrophic and phototrophic sulfur- and sulfide-oxidizing prokaryotes produce sulfate, which is used as electron acceptor in dissimilatory sulfate reduction, an anaerobic respiratory process that regenerates sulfide (Trüper \& Fischer, 1982; Schidlowski, 1986). Phylogenetic analysis of enzymes participating in dissimilatory sulfate reduction and oxidation of reduced sulfur compounds should

Abbreviation: APS, adenosine-5'-phosphosulfate.

The GenBank accession numbers for the nucleotide sequences reported in this paper are U84759 and U84760 provide new insights into the evolution of dissimilatory sulfur metabolism.

Three enzymes appear to be involved in both the oxidative and the reductive mode of dissimilatory sulfur metabolism: ATP sulfurylase, the iron-sulfur flavoprotein adenosine- $5^{\prime}$-phosphosulfate (APS) reductase (EC 1.8.99.2) and sirohaem sulfite reductase (EC 1.8.99.1). All three enzymes are generally found in both sulfate-reducing bacteria and archaea (Thauer, 1989; Fauque et al., 1991; Speich \& Trüper, 1988; Dahl et al., 1990). In addition, the presence of APS reductase and ATP-sulfurylase has been reported for several species of chemotrophic (Takakuwa, 1992) and phototrophic (Trüper \& Fischer, 1982; Fischer, 1989) sulfuroxidizing bacteria. The presence of a sirohaem sulfite reductase with a proposed function in sulfide oxidation has been demonstrated for Thiobacillus denitrificans strain RT and Chromatium vinosum strain D (Schedel \& Trüper, 1979; Schedel et al., 1979). Since APS reductase and sulfite reductase furthermore are highly 
conserved proteins in terms of physicochemical properties (Lampreia et al., 1994; Hatchikian, 1994; Brune, 1989), these enzymes appear to be ideal candidates for phylogenetic analyses. The sequences for sulfite reductase and APS reductase from a hyperthermophilic archaeal (Archaeoglobus fulgidus) and a mesophilic bacterial (Desulfovibrio vulgaris) sulfate reducer (Dahl et al., 1993; Speich et al., 1994; Karkhoff-Schweizer et al., 1995; GenBank accession number Z69372) provided the basis for our work on the evolution of these enzymes, which we now extend to a mesophilic bacterial sulfur oxidizer, the phototrophic bacterium Chr. vinosum.

\section{METHODS}

Bacterial strains and growth conditions. Chr. vinosum strain D (DSMZ 180 ) and Chlorobium limicola f. sp. thiosulfatophilum strain 6230 (DSMZ 249 ) were cultured in medium 2 (Pfennig \& Trüper, 1992) with the $\mathrm{pH}$ adjusted to $7 \cdot 3$ and $6 \cdot 8$, respectively. Ectothiorhodospira mobilis strain $51 / 7\left(\mathrm{DSMZ} 237^{\mathrm{T}}\right.$ ) was grown in the medium described by Imhoff (1992) for extremely halophilic Ectothiorhodospira species with $5 \%(\mathrm{w} / \mathrm{v})$ salinity. Rhodovulum adriaticum strain 6 II (DSMZ 2781 $)$ and Rbodovulum sulfidophilum strain W 4 (DSMZ 1374 ${ }^{\mathrm{T}}$ ) were cultivated in AT medium (Imhoff \& Trüper, 1992) with $5 \%$ salinity and sodium sulfide concentrations of $1 \mathrm{mM}$ and $2 \mathrm{mM}$, respectively. All phototrophic bacteria were grown anaerobically and photolithoautotrophically. The purity of cultures was routinely checked by light microscopy and agar dilution series (Pfennig $\&$ Trüper, 1992). In addition, the results of heterologous PCR (see Results and Discussion) excluded the possibility of contamination by sulfate reducers. Medium and anaerobic growth conditions for T. denitrificans strain RT (DSMZ 807) were essentially as described by Baldensperger \& Garcia (1975). Escherichia coli XL1-Blue (Stratagene) [endA1 hsdR17 $\left(\mathrm{r}_{\mathrm{K}}^{-} \mathrm{m}_{\mathrm{K}}^{+}\right)$supE44 thi-1 $\lambda^{-}$recA1 gyrA96 relA1 (lac) $\left[\mathrm{F}^{\prime}\right.$, proAB lacl $^{\mathrm{q}} \mathrm{Z} \Delta \mathrm{M} 15 \mathrm{Tn} 10\left(\right.$ tet $\left.\left.^{\mathrm{R}}\right)\right]$ and E. coli DH5 $\alpha\left[\mathrm{F}^{-}, \phi 80 \mathrm{~d} l a c Z \Delta \mathrm{M} 15\right.$ $\Delta$ (lacZYA-argF)U169 recA1 endA1 hsdR17 $\left(\mathrm{r}_{\mathrm{K}}^{-} \mathrm{m}_{\mathrm{K}}^{+}\right) \sup E 44 \lambda^{-}$ thi-1 gyrA relA1] were used as host strains for molecular cloning. E. coli strains were grown in LB medium (Sambrook et al., 1989) or in double strength YT medium (Miller, 1972). The media were supplemented with $12.5 \mu \mathrm{g}$ tetracycline $\mathrm{ml}^{-1}$ for E. coli XL1-Blue and with $100 \mu \mathrm{g}$ ampicillin $\mathrm{ml}^{-1}$ for plasmid-containing derivatives.

DNA preparation and PCR primers. Chromosomal DNA from Chr. vinosum and Ect. mobilis was prepared by sarcosyl lysis (Bazaral \& Helinski, 1968) and subsequent $\mathrm{CsCl}$ gradient centrifugation (Sambrook et al., 1989); chromosomal DNA from $R$. sulfidophilum, $R$. adriaticum, Chl. limicola f. sp. thiosulfatophilum and $T$. denitrificans was prepared by the CTAB method (Ausubel et al., 1996), followed by $\mathrm{CsCl}$ centrifugation. Chromosomal DNA from $A$. fulgidus strain VC16 (DSMZ 4304 ${ }^{\mathrm{T}}$ ) was prepared according to Dahl et al. (1993). For PCR analysis, $20 \mathrm{mg}$ cell paste from Desulfovibrio gigas (DSMZ 1382 ) was washed in $100 \mu \mathrm{l}$ TE $\mathrm{pH} 8.0$ (Sambrook et al., 1989) and centrifuged in a microcentrifuge tube at $19000 \mathrm{~g}$ for $20 \mathrm{~s}$. The pellet was resuspended in $100 \mu \mathrm{l}$ TE $\mathrm{pH} 8.0$ and incubated in a boiling water bath for $5 \mathrm{~min}$ (Kretz et al., 1994). After centrifugation at $19000 \mathrm{~g}$ for $2 \mathrm{~min}$, $60 \mu \mathrm{l}$ of the supernatant was pipetted into another microcentrifuge tube; $1 \mu \mathrm{l}$ of this preparation was used as template in PCR. Primers wh5 (5'-GCATTGAAGAGCGAACTGCTTGCT-3') and wh6 (5'-CAATGGCAGGGTTCCAAGTACATG- $3^{\prime}$ ), which correspond to nucleotide positions
445-468 and 2540-2563, respectively, of the apr locus of A. fulgidus (Speich et al., 1994), were used for the generation of the DNA probe Afwh 5 wh $6^{\text {DIG }}$ for APS reductase genes. DNA concentrations were determined by adsorption spectroscopy (Ausubel et al., 1996). Sequences of the degenerate primers for heterologous PCR were as follows, with the nucleotide positions of the respective gene loci given in parentheses: wh53, 5'-TGGGA(G/A)TGCTAC(A/T)(G/C)CTG-3' [A. fulgidus (214-230) (Speich et al., 1994), D. vulgaris (353-369) (GenBank accession number Z69372), Chr. vinosum (211-227) (this work)]; wh54, 5'-C(T/C)GT(G/T) GCCCAGGG(T/C)CT-3' [A. fulgidus (735-750), D. vulgaris (962-977), Chr. vinosum (718-733)]; and wh62, 5'-C(G/T) GTAGTAG(A/T)A(G/T)CC(G/C)GG-3' [ A. fulgidus (23332349), D. vulgaris (2614-2630), Chr. vinosum (22922308)]. The sequencing primers were pUC/M13 forward, $5^{\prime}$-GTAAAACGACGGCCAGT-3'; and pUC/M13 reverse, 5'-GAAACAGCTATGACCATG-3'.

Cloning and DNA sequencing. All general cloning techniques and enzymic manipulations were performed according to standard methods (Ausubel et al., 1996). A clone carrying a $5 \mathrm{~kb}$ HindIII fragment with the complete $a p r B A$ genes was isolated from a library of $4 \cdot 5-5 \cdot 5 \mathrm{~kb}$ HindIII fragments of total Chr. vinosum DNA in the pUC18 vector using the PCRgenerated 400 bp portion of the Chr. vinosum APS reductase gene locus described by $\mathrm{Dahl}$ (1996) as a probe. For cloning of the $d s r$ locus, a library of $3.0-3.9 \mathrm{~kb} E$ EoRI fragments in pUC18 was constructed. Identification of positive clones was achieved by Southern hybridization at $63^{\circ} \mathrm{C}$ of EcoRIrestricted plasmid DNA isolated from randomly picked colonies using a 521 bp PCR-generated probe encoding the sirohaem- $\left[\mathrm{Fe}_{4} \mathrm{~S}_{4}\right]$ binding domain of the $\alpha$-subunit of D. simplex (DSMZ $4141^{\mathrm{T}}$ ) dissimilatory sulfite reductase (Molitor, 1996; GenBank accession number U78738; positions 342-852). Preliminary sequencing indicated that the cloned $3.1 \mathrm{~kb}$ fragment did not contain the $5^{\prime}$-terminus of the $\mathrm{Cbr}$. vinosum $d s r A$ gene. Therefore, the remaining portion of the gene was cloned by chromosome walking on an overlapping $4 \mathrm{~kb}$ Sall genomic DNA fragment, which was isolated from a library of $3.5-4.5 \mathrm{~kb}$ Sall fragments in the pBluescript II $\mathrm{SK}(+)$ vector (Stratagene). To facilitate further manipulations the inserts were recloned into the appropriate sites of pGEM$7 \mathrm{Zf}(+)$ (Promega). Deletion clones were constructed by subcloning of restriction fragments or by unidirectional digestions with exonuclease III (Henikoff, 1984), using the Erase-a-base system (Promega) and following the manufacturer's instructions. Double-stranded DNA sequencing was performed with the Silver Sequence system (Promega), following the manufacturer's instructions except that, for both pUC/M13 forward and reverse primers (see above), the PCR profile 1 with an annealing temperature of $49^{\circ} \mathrm{C}$ was used.

Southern hybridizations. Hybridizations were performed with the digoxigenin (DIG) system (Boehringer) according to the manufacturer's instructions with the following modifications. The prehybridization and hybridization buffers were supplemented with $0.1 \mathrm{mg}$ sonicated herring sperm DNA (Promega) $\mathrm{ml}^{-1}$. The SDS concentration in the wash solutions was $1 \%(\mathrm{w} / \mathrm{v})$. The chemiluminescent substrate CSPD (Promega) was applied to a final concentration of $25 \mu \mathrm{M}$. Other modifications and specifications were as described elsewhere (Hipp, 1996). Probes were labelled with digoxigenin via PCR (Lion \& Haas, 1990) with final concentrations of $20 \mu \mathrm{M}$ DIG-11-dUTP (Boehringer) and $180 \mu \mathrm{M}$ dTTP in the reaction mixture; other conditions were as described 
below. After purification by agarose gel electrophoresis, the gel slice $(50-100 \mathrm{mg})$ containing the labelled amplicon was excised and transferred to a plastic tube filled with $10 \mathrm{ml}$ hybridization buffer. Incubation for $20 \mathrm{~min}$ in a boiling water bath yielded the ready-to-use hybridization solution.

PCR. Hot start PCR (Chou et al., 1992) was performed in a TRIO-Thermoblock thermal cycler (Biometra). Buffer A (10x concentration) consisted of $500 \mathrm{mM} \mathrm{KCl}, 100 \mathrm{mM}$ Tris/ $\mathrm{HCl} \mathrm{pH} \mathrm{8.3,} 15 \mathrm{mM} \mathrm{MgCl}$ and $0.1 \%(\mathrm{w} / \mathrm{v})$ gelatin (Lion \& Haas, 1990). The composition of $10 \times$ buffer B ('SuperTaq buffer', Stehelin \& Cie AG) was $500 \mathrm{mM} \mathrm{KCl}$, $100 \mathrm{mM}$ Tris $/ \mathrm{HCl} \mathrm{pH} 9 \cdot 0,15 \mathrm{mM} \mathrm{MgCl}, 0 \cdot 1 \%$ gelatin and $1 \%(\mathrm{v} / \mathrm{v})$ Triton $\mathrm{X}-100$. Reaction mixtures $(50 \mu \mathrm{l})$ contained 50-250 ng template DNA, $2 \mathrm{U}$ Taq polymerase, $1 \times \mathrm{PCR}$ buffer, $200 \mu \mathrm{M}$ of each dNTP and $1 \mu \mathrm{M}$ of each primer. The temperature profile for the amplification of Afwh $5 \mathrm{wh} 6^{\mathrm{DIG}}$ started with a 5 min denaturation step at $95^{\circ} \mathrm{C}$. Cycling was $20 \mathrm{~s}$ at $55^{\circ} \mathrm{C}, 60 \mathrm{~s}$ at $72{ }^{\circ} \mathrm{C}$ and $30 \mathrm{~s}$ at $95^{\circ} \mathrm{C}$ for 35 cycles followed by an additional annealing step and a final $5 \mathrm{~min}$ elongation step at $72{ }^{\circ} \mathrm{C}$. The thermal profile for the use of degenerate primers consisted, after an initial 3 min denaturation step at $95^{\circ} \mathrm{C}$, of three cycles I $(30 \mathrm{~s}$ at annealing temperature $\mathrm{I}, 0.2{ }^{\circ} \mathrm{C} \mathrm{s}^{-1}$ ramp time to reach $72{ }^{\circ} \mathrm{C}, 1 \mathrm{~min}$ at $72^{\circ} \mathrm{C}, 30 \mathrm{~s}$ at $\left.95^{\circ} \mathrm{C}\right)$ and 30 cycles II $(30 \mathrm{~s}$ annealing temperature II, 1 min at $72{ }^{\circ} \mathrm{C}, 30 \mathrm{~s}$ at $95^{\circ} \mathrm{C}$ ), followed by an additional annealing step at annealing temperature II and a final 5 min elongation step at $72^{\circ} \mathrm{C}$. Annealing temperature I was either $60^{\circ} \mathrm{C}$ (Tdwh54wh62) or $50^{\circ} \mathrm{C}$ (all others); annealing temperature II was either $50^{\circ} \mathrm{C}$ (Tdwh54wh62) or $40^{\circ} \mathrm{C}$ (all others). With DNA from Chl. limicola f. sp. thiosulfatophilum and $T$. denitrificans buffer $\mathrm{A}$ was used, while with all other templates buffer B gave better results.

\section{RESULTS AND DISCUSSION}

\section{Description of the apr locus from Chr. vinosum, and alignment with sequences from $A$. fulgidus and D. vulgaris}

In a BLASTX analysis (Gish \& States, 1993; Altschul et al., 1990; blast@ncbi.nlm.nih.gov) a 2567 bp DNA region containing the apr locus from Chr. vinosum revealed high statistical similarities with smallest sum probabilities equal or less than $1 \cdot 8 \times 10^{-35}$ to sequences encoding the subunits of the APS reductases from $A$. fulgidus and $D$. vulgaris. These similarities correspond to two ORFs whose termination and ATG initiation codons overlap in the sequence TGATG. The shorter ORF (nt 85-567) was found to encode a 160 aa polypeptide with a computed molecular mass of $18175 \mathrm{Da}$. Translation of the larger ORF (nt 567-2429) yields a 620 aa polypeptide with a computed molecular mass of $69543 \mathrm{Da}$. The identification of the two ORFs as the genes $a p r B$ and $a p r A$ for two different subunits of the APS reductase from Chr. vinosum is strongly supported by the fact that insertional inactivation of aprBA in Chr. vinosum leads to an inability of the organism to synthesize APS from sulfite and AMP (Dahl, 1996). Putative ribosome-binding sites (RBS) (AAGAGG, AGCAGG) are properly located immediately upstream of each of the two ORFs. Whilst a promoter-like structure was not evident within the $84 \mathrm{bp}$ upstream of the putative initiation codon of $a p r B$, an inverted repeat which gives rise to a stable stem-loop structure $\left(\Delta \mathrm{G}=-35.0 \mathrm{~kJ} \mathrm{~mol}^{-1}\right.$, identified and calculated by DNASIS, Hitachi) immediately followed by a poly(dT) stretch, typical for a rho-independent terminator (Richardson, 1993), is located $28 \mathrm{bp}$ downstream of the aprA stop codon.

For greater clarity, in the following text the sequences from $D$. vulgaris are also named apr instead of aps (GenBank accession number Z69372). Alignments of the deduced amino acid sequences from the respective genes from A. fulgidus, D. vulgaris and Chr. vinosum show regions of statistically significant similarity with a large number of conserved residues spanning almost the entire polypeptides (Fig. 1a, b). Moreover, common secondary structures as predicted by several programs are found even in regions that exhibit no statistically significant sequence similarities.

With respect to the special molecular characteristics of APS reductases, Speich et al. (1994) found a high sequence similarity between the flavoprotein subunit (AprA) of APS reductase from $A$. fulgidus and succinate dehydrogenases and fumarate reductases. To verify this result, a BLOCKS search was performed to identify short multiply aligned ungapped segments corresponding to the most highly conserved regions of proteins (Henikoff \& Henikoff, 1994; blocks@howard.fhcrc.org). With AprA from A. fulgidus, six of eight blocks of the PROSITE (Bairoch, 1992) entry PS00504 ('fumarate reductase/succinate dehydrogenase FAD-binding site proteins') were recognized. The respective polypeptides from Chr. vinosum and D. vulgaris seemed to be less related to this protein family, as only four of eight blocks scored highly enough to be reported. Nevertheless, the general assignment of the flavoprotein subunits of APS reductases to the aforementioned protein family justified the extension of a comparative analysis to the new data. All essential predictions made by Speich et al. (1994) concerning functionally important regions are supported by our findings. For clarity only the positions in the sequences of the polypeptides from Chr. vinosum are given here. The corresponding positions in their homologues can be inferred from Fig. 1.

In addition to the segments described by Speich et al. (1994), a long carboxy-terminal stretch appears to be functionally important for FAD binding. This stretch comprises residues $492-581$ and it shows statistically significant sequence similarities with the flavoprotein subunits of fumarate reductases, succinate reductases and L-aspartate oxidases (double-underlined in Fig. 1b). Robinson \& Lemire (1996) removed the 70 carboxyterminal residues of the flavoprotein subunit of succinate dehydrogenase from Saccharomyces cerevisiae. The residual polypeptide was no longer able to bind FAD.

The centre of AprA contains a strictly conserved undecapeptide (residues 247-257). Due to its agreement with the 'core' fingerprint for ADP-binding folds (Wierenga et al., 1986) and the structural similarity of ADP and APS, Speich et al. (1994) predicted that this region is part of the APS-binding site. The replacement of a neutral hydrophobic residue by a charged residue 
(a) AprB

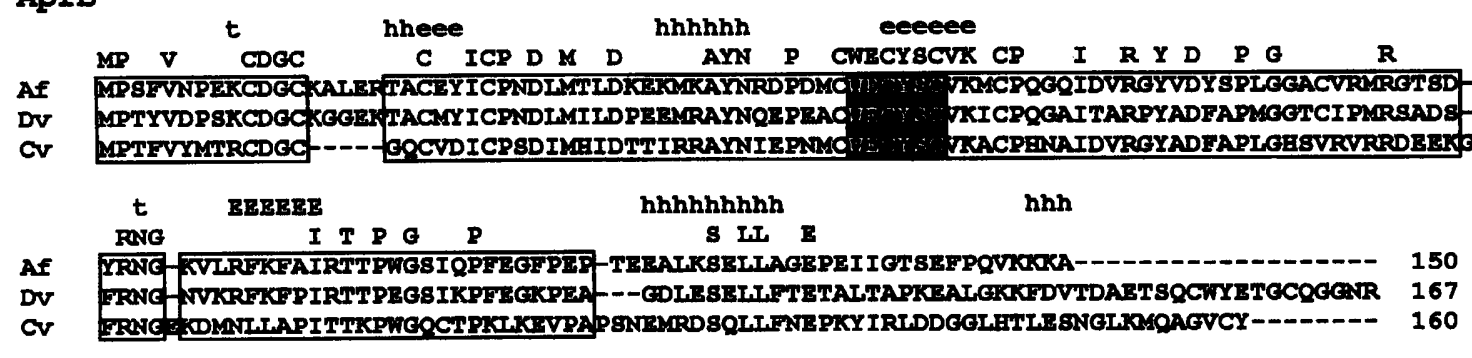

(b) ApxA

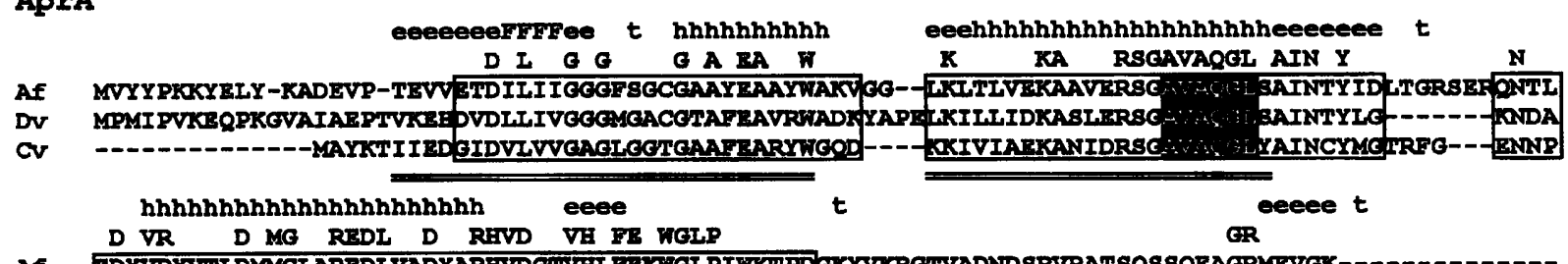

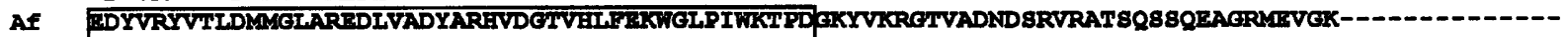

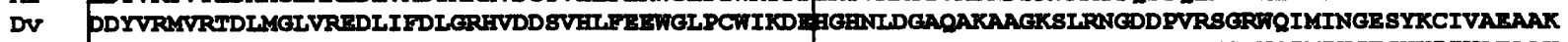

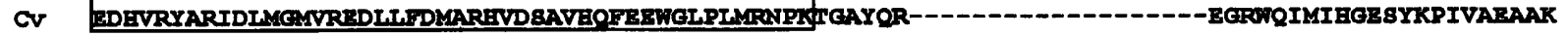

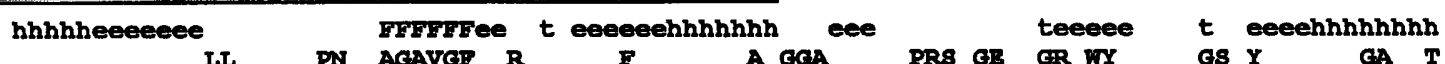

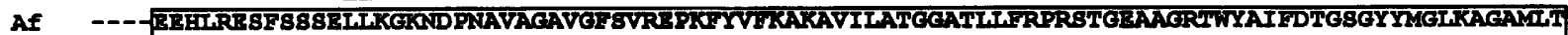

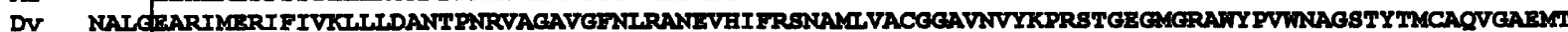

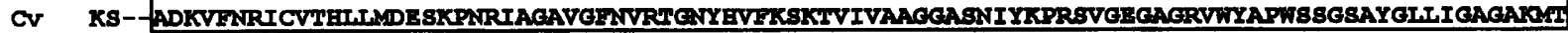

hhneeeeee $t$ ceeeee thhhhh $t$ hhh

E R RFIDGYGPVA FL $X$ N GE $Y$ I IPT LFANA $E$ G PI M T

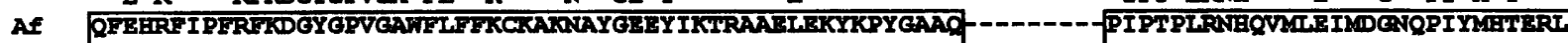

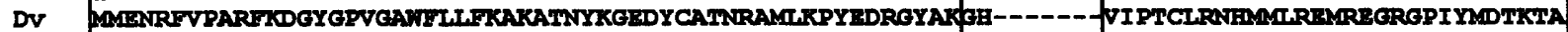

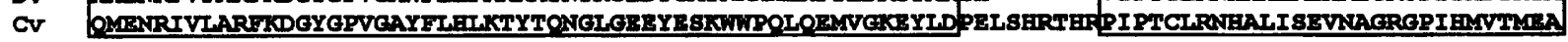
$\overline{\overline{n i n}}$

hhh

\section{hhhhhhhhhhhh}

FI $M V$ OA INA $P$ P $\quad E$ $\boldsymbol{E}$

$t$ hhhhhhh

I

eece YNRM

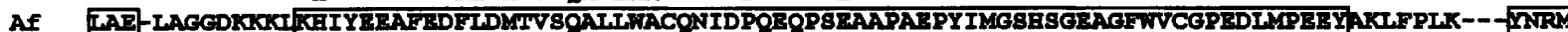

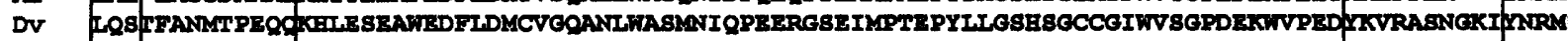

Cv EOD -

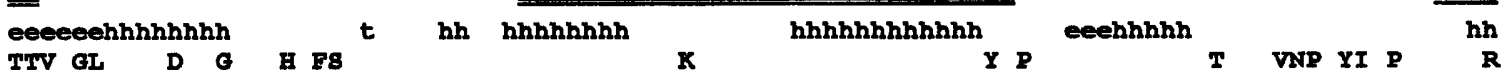

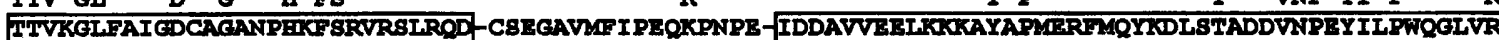

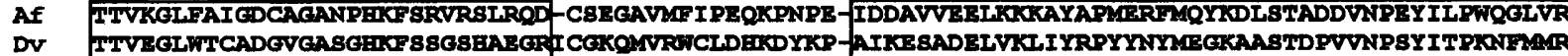

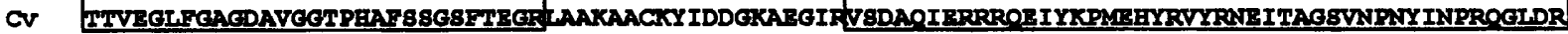

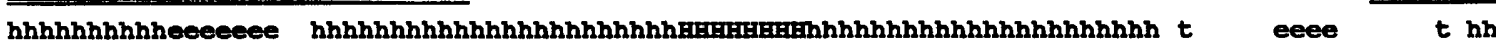

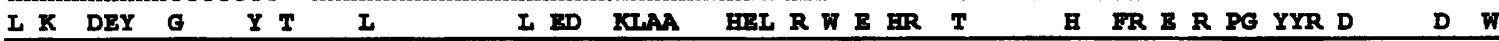

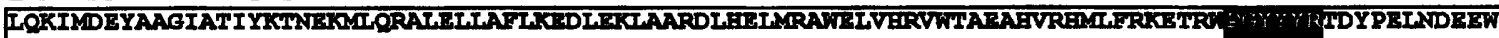

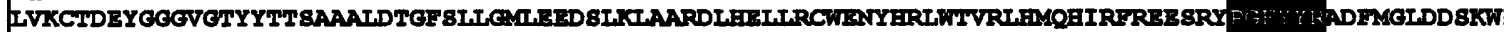

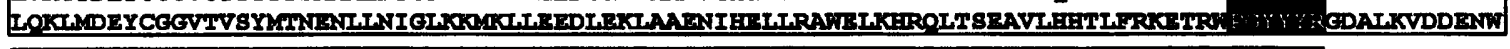

Fig. 1. Alignment of deduced amino acid sequences from the structural genes for AprB (a) and AprA (b) subunits of APS reductases in A. fulgidus (Af), D. vulgaris (Dv) and Chr. vinosum (Cv). The alignment was performed with MACAW (Schuler et al., 1991) with the substitution matrix BLOSUM 62 (Henikoff \& Henikoff, 1992). Blocks of statistically significant similarities among homologous polypeptides are boxed. Strictly conserved residues are given in the line immediately above the alignments. In the top line, the consensus secondary structures as calculated by SSPRED (Mehta et al., 1995; sspred@embl-heidelberg.de) and the soPMA server (Geourjon \& Deleage, 1995; deleage@ibcp.fr) are given: e, any sheet; E, amphiphilic sheet according to West \& Hecht (1995); F, hydrophobic sheet; $h$, any helix; $H$, amphiphilic helix according to West \& Hecht (1995); t, turn. Regions of statistically significant sequence similarity to succinate dehydrogenases, fumarate reductases and $L$-aspartate oxidases are indicated by double lines below the alignments. Degenerate primers for heterologous PCR were derived from the hexapeptides shown on a black background. Note that the composition of the figure reflects the arrangement of the structural genes (aprBA). 

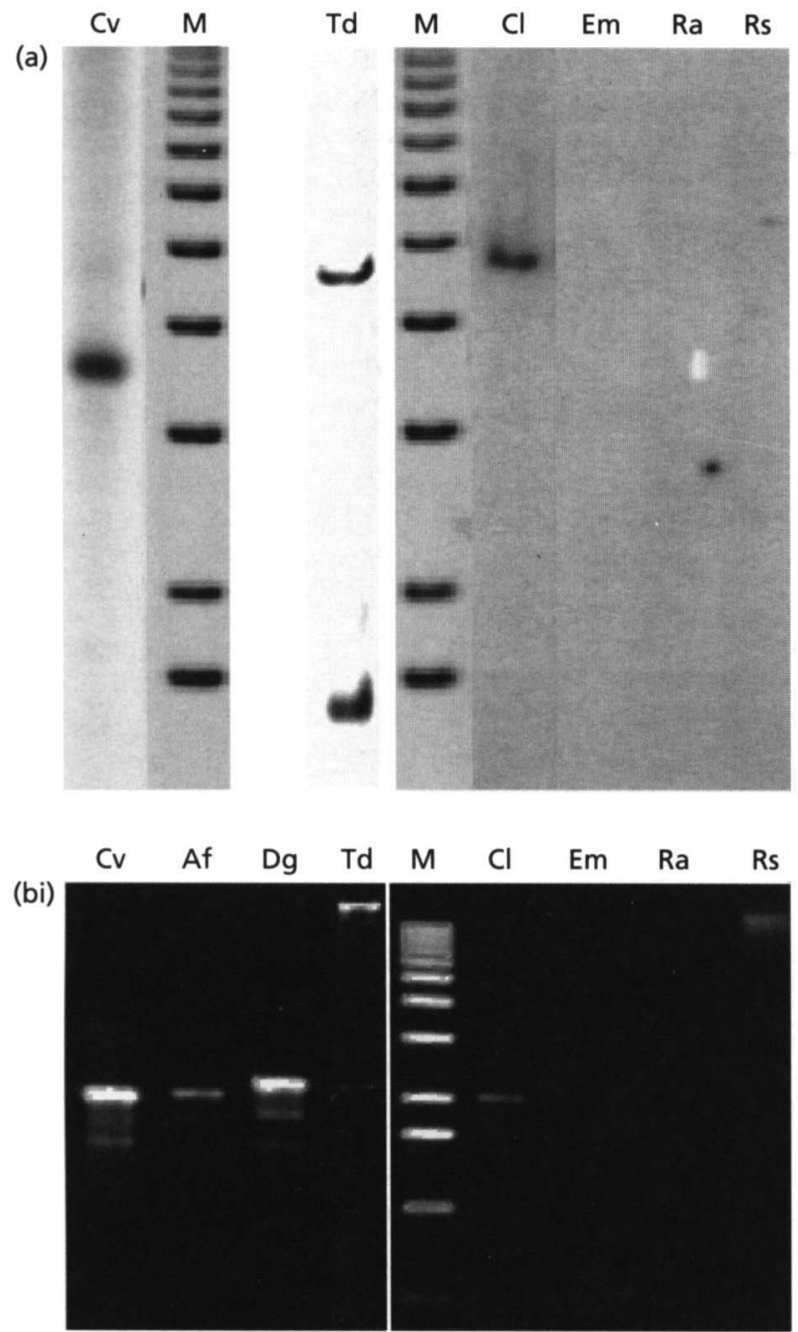

(bii)
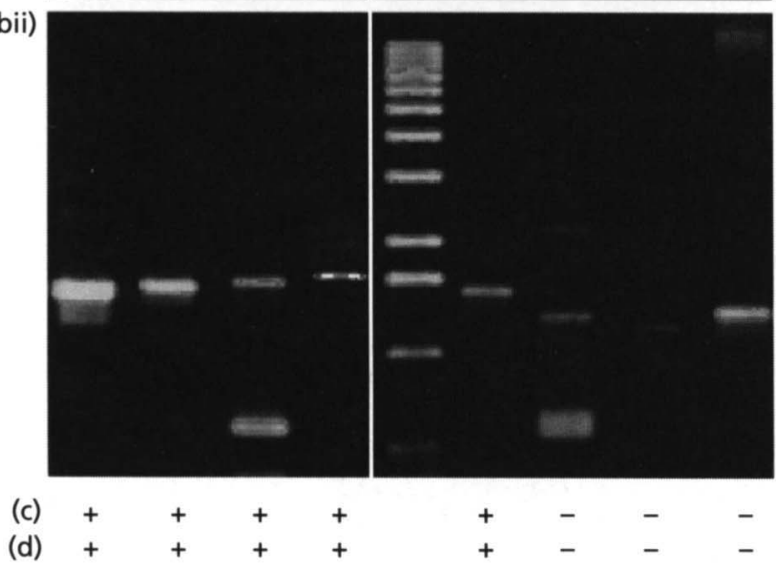

$\begin{array}{rrrr}+ & - & - & - \\ + & - & - & -\end{array}$

Fig. 2. Comparison of the results of Southern hybridization and heterologous PCR with enzymological evidence. (a) Detection of apr homologous regions in the genomes of representative sulfur-oxidizing bacteria by Southern hybridization with the heterologous probe Afwh5wh6 ${ }^{\mathrm{DIG}}$. $\mathrm{Cv}_{\mathrm{r}} \mathrm{Chr}$. vinosum (Xhol/Hindlli, $3.6 \mathrm{~kb}$ ); Td, T. denitrificans (BamHI, $1.4 \mathrm{~kb}$ and $4.5 \mathrm{~kb}) ; \mathrm{Cl}$, Chl. limicola f. sp. thiosulfatophilum (Clal, $4.8 \mathrm{~kb}$ ); Em, Ect. mobilis (Clal); Ra, R. adriaticum (Clal); Rs, $R$. sulfidophilum (Clal); M, $1 \mathrm{~kb}$ ladder (Promega). Fragment sizes corresponding to the signals obtained are given in parentheses. Repeated experiments with different DNA loads consistently yielded the same results. (b) Amplification of apr homologous
(Lys-263), however, does not favour an ADP-binding fold (Wierenga et al., 1986) and none of the programs used in this study predicted a suitable secondary structure. Recently, Moodie et al. (1996) stated that adenylate binding can be achieved by a large number of alternative arrangements. Adenylate-binding regions showed high frequencies of arginine, tyrosine and glycine, whereas glutamate rarely occurred. The region from residues 167 to 240 , which is highly conserved in the AprA polypeptides and the related proteins succinate dehydrogenases, fumarate reductases and L-aspartate oxidases (Fig. 1b, double-underlined), is interrupted by a nonapeptide present only in the AprA sequences. In accordance with the observations of Moodie et al. (1996), this nonapeptide contains strictly conserved glycine, arginine, tryptophan and tyrosine residues (residues 212-220). It is, therefore, tempting to assume that both this nonapeptide and the strictly conserved undecapeptide mentioned above are involved in APS binding. This is supported by the observation that the undecapeptide in the AprA sequences is immediately followed by a stretch of 24 amino acid residues that does not occur in the aligned sequences of succinate dehydrogenases, fumarate reductases and L-aspartate oxidases. The latter sequences, however, contain a segment of almost the same size immediately before the undecapeptide, which has no counterpart in the AprA sequences (data not shown). This segment is known to comprise the active centre of succinate dehydrogenases and fumarate reductases (Schröder et al., 1991).

While the AprA subunits of APS reductases from the chemotrophic sulfate reducers $A$. fulgidus and $D$. vulgaris and the phototrophic sulfur oxidizer Chr. vinosum do not differ fundamentally, there are obvious differences between the respective AprB subunits (Fig. 1a). As already stated by Speich et al. (1994), AprB from A. fulgidus contains an arrangement of cysteine residues characteristic for Azotobacter-type (7-Fe) ferredoxins; the same arrangement is found in AprB from $D$. vulgaris. In contrast, the cysteine arrangement in AprB from $\mathrm{Chr}$. vinosum fits the pattern of Clostridium-type (8-Fe) ferredoxins (Iwasaki et al., 1994), i.e. it lacks five amino acid residues in the amino-terminal cluster-binding region. Despite possessing an identical arrangement of

regions by heterologous PCR. (bi) Results of PCR with the primer pair wh53wh62; (bii) results of PCR with primer pair wh54wh62. DNA from the bacteria listed above and from $A$. fulgidus (Af) and $D$. gigas $(\mathrm{Dg})$ served as templates. Note that the visible amplicons in lanes Em, Ra and Rs of panel (bii) were not of the anticipated size. Ethidium-bromide-stained gels and Kodak XAR-5 films were recorded with a CREAM CGS documentation system (Intas), sizes of restriction fragments and amplicons were determined using the CREAM 1-D software (Intas). (c) Verification of PCR results by Southern hybridization with the heterologous probe Afwh 5 wh $6^{\mathrm{DIG}}$. The presence $(+)$ or absence $(-)$ of distinct signals obtained with each amplicon shown in (b) is qualitatively summarized. As the results for wh53wh62 and wh54wh62 amplicons were absolutely congruent, the statement is valid for either primer pair. (d) Enzymological evidence for the presence $(+)$ or absence $(-)$ of an APS reductase. References are given in the text. 
cysteine residues, different spectroscopic properties were reported for the APS reductases from $A$. fulgidus and $D$. vulgaris (Lampreia et al., 1991; Verhagen et al., 1994). Therefore it would seem premature to discuss putative functional implications of the different cysteine arrangements before spectroscopic data for the APS reductase from $\mathrm{Cbr}$. vinosum are available. Whether the additional residues at positions 81, 82 and 93 in AprB from Chr. vinosum are of any functional or structural importance needs to be the subject of further studies.

The lack of signal peptides and transmembrane segments as predicted by signalP (Rapacki, Center for Biological Sequence Analysis, Lyngby; http: //www.cbs.dtu.uk/signalp/cbssignalp.ms.html) and PSORT (Nakai, Institute for Molecular and Cellular Biology, Osaka; http://psort.nibb.ac.jp) characterize the gene products AprA and AprB from Chr. vinosum, together with all other polypeptides examined in this study, as cytoplasmic and soluble. This result is in contradiction to the finding that APS reductase activity is firmly membrane-bound in Chr. vinosum (Schwenn \& Biere, 1979). The situation may be analogous to the succinate-ubiquinone oxidoreductase from $E$. coli. Here, hydrophobic subunits anchor the hydrophilic flavoprotein and iron-sulfur protein subunits to the cytoplasmic membrane (Nakamura et al., 1996).

\section{Design of a heterologous DNA probe and PCR conditions for the detection and amplification of apr genes}

A gene probe must meet the criterion of specificity and selectivity. AprA, the large subunit of the APS reductase from $A$. fulgidus, contains the putative substratebinding site, region(s) that should be conserved in all APS reductases (Speich et al., 1994). A DNA probe was prepared by PCR amplification and nonradioactive labelling of the entire aprA gene as specified in Methods.

Genomic DNA from representatives of the purple sulfur bacteria (Chr. vinosum, Ect. mobilis), nonsulfur purple bacteria ( $R$. sulfidophilum, $R$. adriaticum), green sulfur bacteria (Chl. limicola f. sp. thiosulfatophilum), and thiobacilli ( $T$. denitrificans) was subjected to Southern hybridization with the aprA gene as a probe. Fig. 2(a) shows the results of hybridization obtained under conditions of low stringency $\left(55^{\circ} \mathrm{C}\right)$. Distinct signals were only obtained with restricted DNA from $\mathrm{Cbr}$. vinosum, $T$. denitrificans and Chl. limicola $\mathrm{f}$. $\mathrm{sp}$. thiosulfatophilum.

The alignments of amino acid sequences of AprA and AprB revealed several highly conserved regions. For primer design, hexapeptides were chosen that were located as close as possible to the termini of the polypeptides to maximize amplicon size (Fig. 1). From the positions in the respective gene loci as given in Methods, wh53wh62 amplicons were expected to be in the range of $2.2 \mathrm{~kb}$ and wh54wh62 amplicons in the range of $1.6 \mathrm{~kb}$. In addition to the bacteria listed above, DNA from $A$. fulgidus and D. gigas was used as template. Fig. 2(bi) and (bii) show the results of PCR experiments with the primer pairs wh53wh62 and wh54wh62, respectively. While all other amplicons were obtained with high reproducibility under the conditions stated here, this did not apply for Tdwh53wh62 (Fig. 2bi). Obviously, the primer pair wh54wh62 worked less selectively than wh53wh62, as is shown by visible amplicons obtained with DNA from Ect. mobilis, $R$. adriaticum and $R$. sulfidophilum (Fig. 2bii). These amplicons, however, did not have the anticipated size (see above). To verify that the properly sized amplicons actually did and the improperly sized ones did not correspond to $a p r$ homologous regions, the amplicons were probed with Afwh 5 wh $6^{\text {DIG }}$. The qualitative results are summarized in Fig. $2 \mathrm{c}$ and were positive for both wh53wh62 and wh54wh62 amplicons.

All results correlate perfectly with enzymological data (Fig. 2d): whereas the presence of APS reductase in Chr. vinosum, Chl. limicola f. sp. thiosulfatophilum, $T$. denitrificans and D. gigas is well-documented (Dahl, 1996; Schwenn \& Biere, 1979; Kirchhoff \& Trüper, 1974; Bowen et al., 1966; Lampreia et al., 1990), the enzyme is generally considered to be absent in the Rhodospirillaceae and Ectothiorhodospiraceae (Neutzling et al., 1985; Trüper \& Fischer, 1982). Moreover, the amplification of apr homologous regions with the primer pair wh53wh62 proves the gene order $a p r B A$ in the genomes of $D$. gigas, Chl. limicola $\mathrm{f}$. sp. thiosulfatophilum and $T$. denitrificans. The absolute consistency of all data demonstrates that the DNA probe and PCR conditions described in this work are excellent diagnostic tools and will aid in the acquisition of further data.

\section{Description of the dsr locus from Chr. vinosum and alignment with sequences from $A$. fulgidus and D. vulgaris}

A BLASTX analysis of a $2567 \mathrm{bp}$ DNA region from $\mathrm{Chr}$. vinosum led to the identification of two ORFs. Their inferred translation products exhibited high statistical similarities with smallest sum probabilities equal to or less than $9.2 \times 10^{-75}$ to the subunits of the dissimilatory sulfite reductases from $A$. fulgidus and $D$. vulgaris. The first ORF (nt 22-1275) was found to encode a 417 aa polypeptide with a computed molecular mass of $46791 \mathrm{Da}$. Translation of the second ORF (nt 13302400) yielded a 356 aa polypeptide with a computed molecular mass of $39983 \mathrm{Da}$. Putative RBSs (AGGAG, GGAGG) are located immediately upstream of the two ORFs. The reported molecular masses of the two subunits of Chr. vinosum sulfite reductase, $42 \mathrm{kDa}$ and $37 \mathrm{kDa}$ (Schedel et al., 1979), are in good agreement with the computed data for the gene products of ORF1 and ORF2, respectively. As Schedel et al. (1979) did not detect any other sirohaem-containing protein in $\mathrm{Chr}$. vinosum and the sequence requirements for sirohaembinding are met (see below), ORF1 and ORF2 very likely represent the structural genes $d s r A$ and $d s r B$ for the sulfite reductase described by Schedel et al. (1979). In contrast to the situation in D. vulgaris and A. fulgidus (Karkhoff-Schweizer et al., 1995), an ORF homologous 


Dsr
AfA
DVA
CVA
AfB
DVB
CVB


AfA
DVA
CVA
AfB
DVB
CVB

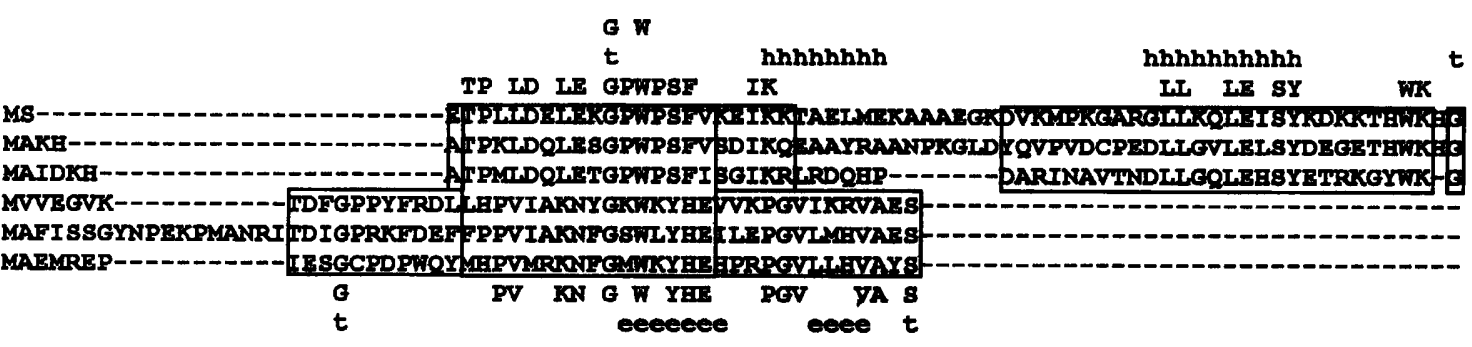

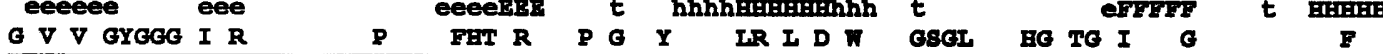

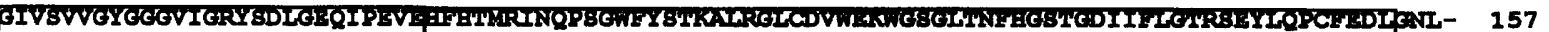

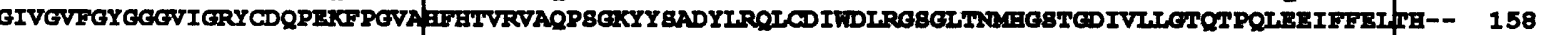

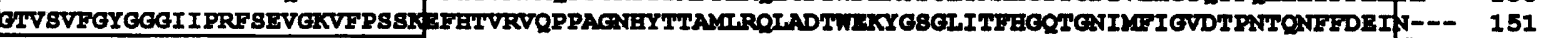

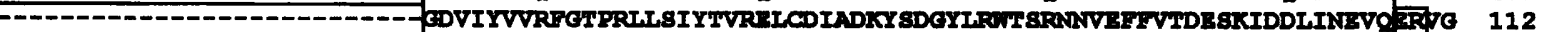

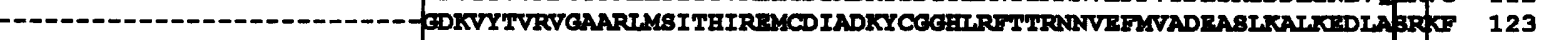

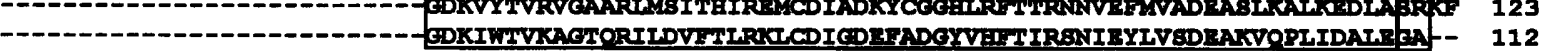

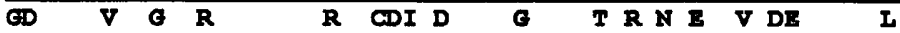

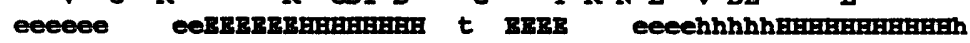

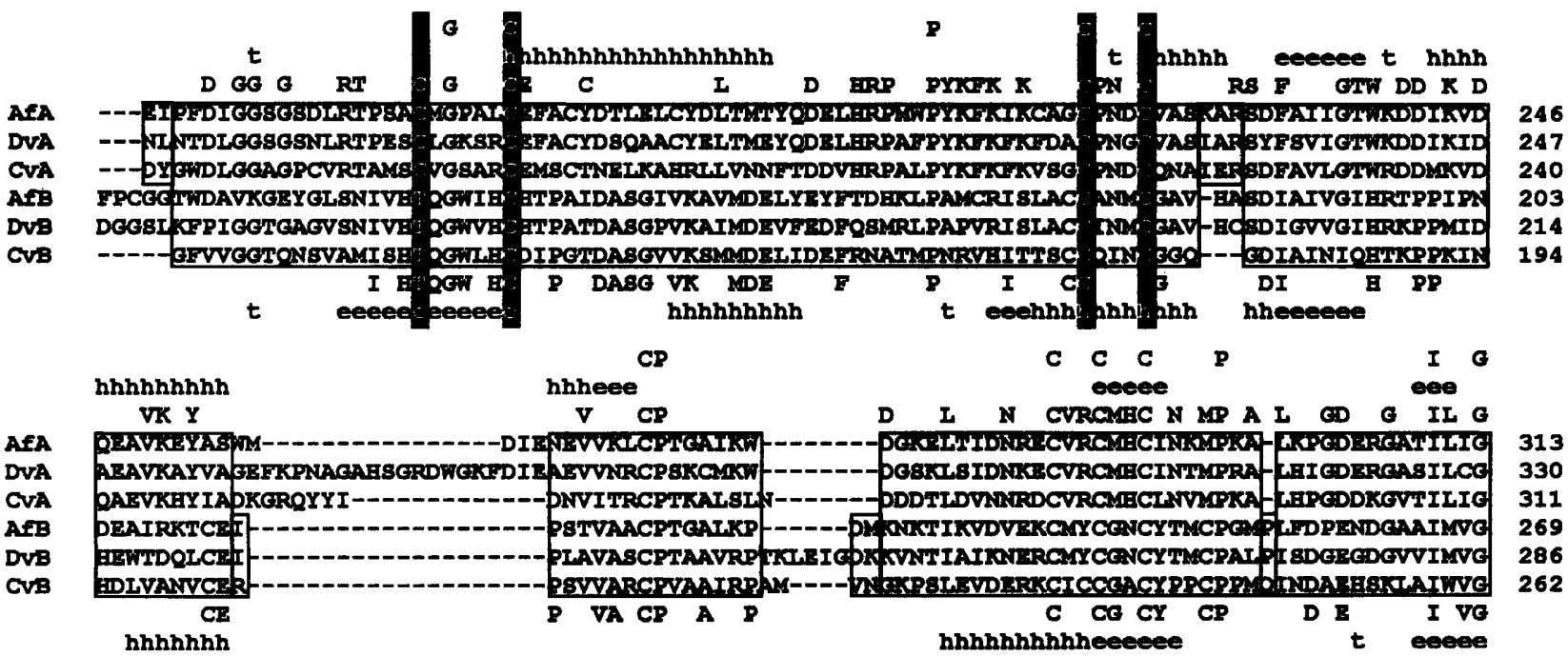

Whhhhhh

$\checkmark$ hhhhh QeeFFFFF $x$ G $G$ VPF GKAPEVBGAVIGWVAVPY-

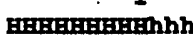
ER $\mathbf{E} R$

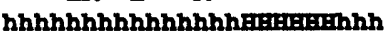

AfA

Dva

CVA

AfB

Dvs

CVB

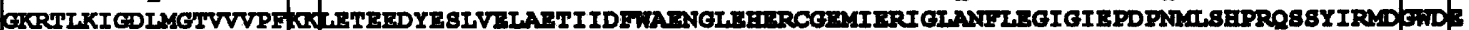

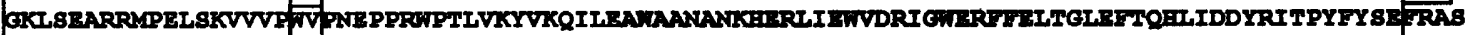

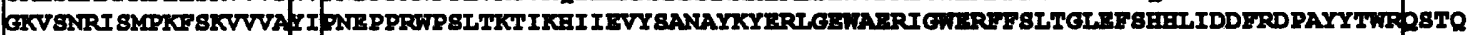

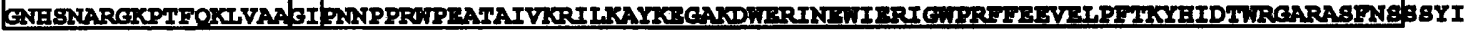
G 8 P K V PN PPRWP $\mathbf{K} I$ A IR BH RIG RFF I $F$ ID $R$

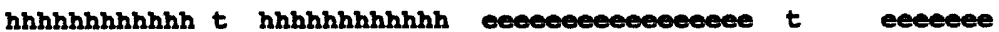

Fig. 3. Alignment of deduced amino acid sequences from the structural genes for the $\alpha-(-A)$ and $\beta$ - (-B) subunits of sulfite reductases from $A$. fulgidus (Af), D. vulgaris (Dv) and Chr. vinosum (Cv). The features are the same as for Fig. 1 with the exception that residues found in all sequences are given in the top line above the sequences. The positions of residues of the cys motif are shown on a black background. 
to $d s r / d s v D$ was not found downstream of $d s r B$. To avoid confusion, in the following text the sequences from $D$. vulgaris are also named $d s r$ instead of $d s v$ (Karkhoff-Schweizer et al., 1995). The extent of similarity between the primary and secondary structures of the respective polypeptides from $A$. fulgidus, D. vulgaris and Chr. vinosum is depicted in Fig. 3. Again, the large number of residues conserved in all sequences is striking.

The most conserved sequence pattern in sirohaemcontaining sulfite reductases and nitrite reductases is the succession of two cysteine clusters with the consensus sequences Cys- $\mathrm{x}_{5}$-Cys and Cys- $\mathrm{x}_{3}$-Cys. The existence of this 'cys motif' (Campbell \& Kinghorn, 1990) is the essential prerequisite for coupling of the $\left[\mathrm{Fe}_{4} \mathrm{~S}_{4}\right]-$ sirohaem cofactor (Ostrowski et al., 1989; Crane et al., 1995). This means that the loss of only one of these cysteines would result in the inability to bind the cofactor. As in the dissimilatory sulfite reductases from A. fulgidus and D. vulgaris (Dahl et al., 1993; KarkhoffSchweizer et al., 1995), only DsrA from Chr. vinosum contains a complete cys motif, whereas the cys motif in DsrB appears to be truncated (Fig. 3, positions shown on a black background). Another common feature of dissimilatory sulfite reductases is the existence of ferredoxin-like domains (Dahl et al., 1993). In the polypeptides from Chr. vinosum these domains include residues 264-290 in DsrA and residues 211-240 in DsrB. Some differences are also evident between the polypeptides from the chemotrophic sulfate reducers and those from the phototrophic sulfur oxidizer. Both subunits of the enzymes from $A$. fulgidus and D. vulgaris contain histidine residues (His-44 in AfDsrA, His-186 in AfDsrB) and heptapeptides (residues 32-38 in AfDsrA, 112-118 in AfDsrB) that do not occur in the Chr. vinosum polypeptides, while Ser-270, Lys-330 and Lys331 are only found in DsrA from Chr. vinosum (Fig. 3). These differences may reflect the role of sulfite reductase in the reductive versus the oxidative pathway.

The view that the structural genes encoding the $\alpha$ - and $\beta$ subunits of sulfite reductase resulted from a duplication of a common ancestral gene (Dahl et al., 1993) is supported by several observations. (1) Segments of statistically significant similarity between the nucleotide sequences of $d s r A$ and $d s r B$ are still found with the Gibbs sampler (Lawrence et al., 1993) implemented in MACAW. These segments correspond to amino acids 109-124 (67-82), 203-218 (160-175), 276-295 (226-245) and 360-376 (309-325) in CvDsrA (CvDsrB) and to the aligned sequences of the respective counterparts from $A$. fulgidus and D. vulgaris (Fig. 3). (2) There is a large extent of statistically significant similarity between the amino acid sequences of DsrA and DsrB (boxed regions extending over DsrA and DsrB sequences in Fig. 3) covering at least $70 \%$ of the total amino acid residues of each polypeptide. To support the assumption that the reading frame has always been similarly maintained in $d s r$ sequences, multiple alignments with translation of all frames were performed (Lockhart et al., 1996). This ruled out insertion and deletion events resulting in frameshifts.
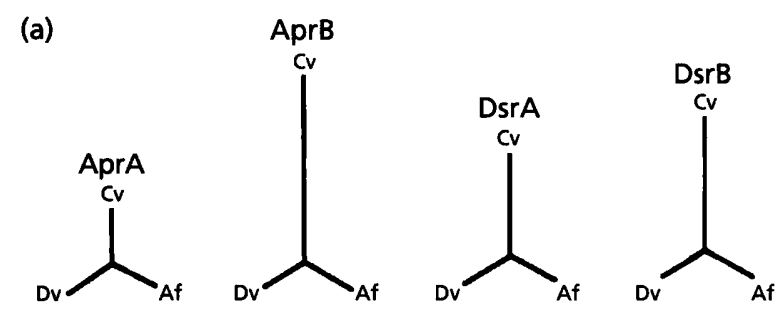

(b)

A

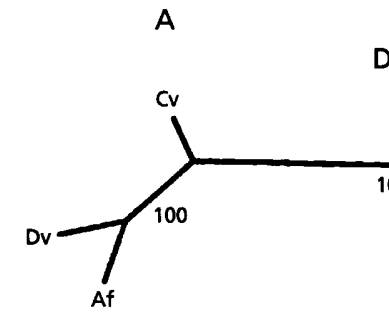

Dsr

\section{B}

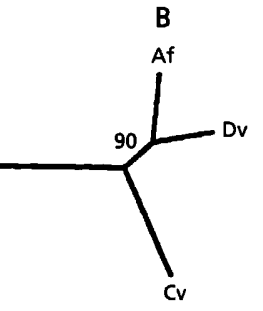

Fig. 4. (a) Topologies of phylogenetic relationships of the subunits of APS reductases (Apr) and sulfite reductases (Dsr) from $A$. fulgidus (Af), D. vulgaris (Dv) and Chr. vinosum (Cv). The unrooted trees were constructed by the neighbour-joining method (Saitou \& Nei, 1987). Only unambiguously aligned residues as estimated by statistically significant sequence similarities were included for the analyses; gaps in the data sets were avoided. The distances from which the trees were inferred are based on the blocks of statistically significant similarities as delineated in Figs 1 and 3. The values according to the PAM 001 matrix (Dayhoff, 1978) for Af-Dv, Dv-Cv and Af-Cv, respectively, are: AprA, 0.87, 0.91, 0.87; AprB, 0.47, 1.05, 1.10; DsrA, 0.65, 0.98, 0.96; and DsrB, 0.58, 1.03, 1.05. The values represent the expected percentage change between two amino acid sequences. (b) Topology of the phylogenetic relationships of the $\alpha$ - and $\beta$-subunits of the dissimilatory sulfite reductases from $A$. fulgidus, $D$. vulgaris and Chr. vinosum. The distances from which the tree was inferred are based on the alignment shown in Fig. 3. The values are: AfDsrA-AfDsrB, 3.02; DvApsA-DvApsB, 2.98; and CvDsrA-CvDsrB, 2.70. The unrooted tree was calculated by the Fitch-Margoliash least-squares method (Fitch \& Margoliash, 1967) without the assumption of a molecular clock. The sum of squares for the tree is 0.028 , and the average per cent standard deviation is 3.173 with 2217 trees being examined. Bootstrap values (given in per cent of 500 replicates) that support particular nodes are indicated on the tree. The trees in (a) were constructed by the successive use of PROTDIST, NEIGHBOR and DRAWTREE. For the tree shown in (b) FITCH (with global rearrangements being allowed and jumbling of data set entry for 50 times) was applied instead of NEIGHBOR. Bootstrap analyses were performed by the successive use of SEQBOOT, PROTPARS and CONSENSE. All these programs are parts of the PHYLIP package (Felsenstein, 1993).

\section{Phylogenetic analyses}

The observed high long-range similarities in nucleotide (data not shown) and amino acid (Figs 1,3 ) sequences, together with the similar physico-chemical properties of the polypeptides indicated that AprA, AprB, DsrA and DsrB from Chr. vinosum and from the sulfate reducers A. fulgidus and D. vulgaris did not evolve convergently but are true homologues (Doolittle, 1994). It therefore appeared justifiable to calculate evolutionary distances derived from the amino acid sequences.

The tree topologies in Fig. 4 show essentially no difference between the distances of the polypeptides 
from Chr. vinosum to those of D. vulgaris, and of the polypeptides from $C h r$. vinosum to those of $A$. fulgidus, respectively. The distances from the $D$. vulgaris to the $A$. fulgidus polypeptides are equal (AprA) or smaller (all others) than those from the Chr. vinosum to the $A$. fulgidus polypeptides. The observed tree topologies are not congruent with the 16S-rRNA-based phylogeny of the source organisms which places the two proteobacteria Chr. vinosum and D. vulgaris far away from the archaeon A. fulgidus (Olsen et al., 1994). Two different possibilities could explain the observed tree topologies. First, a recent lateral gene transfer could have occurred. However, lateral gene transfer is a rare event in prokaryotes (Cohan, 1996) and the fact that all apr and $d s r$ genes from the proteobacteria D. vulgaris and Chr. vinosum show the same strong synonymous codon bias (data not shown), as would be expected for phylogenetically closely related organisms with similar G + C content (Osawa et al., 1992) argues against lateral gene transfer. As the establishment of the optimized codon usage is regarded to be a very slow process (Diaz-Lazcoz et al., 1995), the conspicuously different synonymous codon bias in the apr and $d s r$ genes from $A$. fulgidus implies a primordial split of the A. fulgidus and the proteobacterial lineages. The existence of highly conserved stretches in interchanging sequence pairs (Figs 1, 3 ) is also incompatible with lateral gene transfer.

The observed tree topologies can be better explained by the assumption that the sulfur-metabolizing enzymes from sulfur-oxidizing and sulfate-reducing organisms are not orthologous but paralogous (Gogarten, 1994) proteins. In the latter case, the protogenotic (Benner $e t$ al., 1989; Benner \& Ellington, 1990) precursors of sulfite reductases and APS reductases would have evolved into two independent lineages with the enzymes working in the reductive direction in one and in the oxidative direction in the other prior to divergence into the imperia (Trüper, 1994) Bacteria and Archaea. A comparable concept has been suggested for the evolution of glutamate dehydrogenase gene families I and II (Benachenhou-Lahfa et al., 1993). Our hypothesis of a dichotomic evolution of the sulfur-metabolizing enzymes is supported by the observation that monoclonal and polyclonal antibodies directed against APS reductase from Desulfovibrio desulfuricans strain G100A cross-react strongly with extracts from other sulfate-reducing bacteria, but only weakly if at all with extracts from the sulfur-oxidizing bacteria $T$. denitrificans, Chr. vinosum and Chl. limicola f. sp. thiosulfatophilum (Odom et al., 1991). Polyclonal antibody against the sulfite reductase from A. fulgidus crossreacts with the respective enzyme from the bacterial sulfate reducer Thermodesulfobacterium commune (Dahl et al., 1993), but only very poorly with extracts from Chr. vinosum and T. denitrificans (data not shown). In addition, we were not able to amplify parts of the dsr loci from Chr. vinosum and T. denitrificans with essentially the same PCR primers that KarkhoffSchweizer $e t$ al. (1995) used to amplify parts of the $d s r$ loci from diverse bacterial sulfate reducers. Further- more, Southern hybridizations with parts of the $d s r$ loci from $A$. fulgidus, D. gigas (GenBank accession number U80961) and Chr. vinosum as probes revealed a distinctly higher similarity of the $d s r$ locus from $T$. denitrificans to the dsr locus from Chr. vinosum than to the $d s r$ loci from the two sulfate reducers (data not shown).

The tree shown in Fig. 4(b) strongly suggests that the duplication of the common ancestor of the $d s r$ genes must have occurred prior to entering the lineages leading to the contemporary sequences, as $\alpha$ - and $\beta$-subunits are more closely related among themselves than to each other in one organism. The dyad symmetry of the tree can easily be explained when constant evolutionary rates of the $\alpha$ - and $\beta$-subunit lineages are assumed. This assumption was confirmed by the two-cluster test of Takezaki et al. (1995) as implemented in PHYLTEST (Kumar, 1996) with those sirohaem-binding proteins least distant to the $\alpha$-and $\beta$-subunits as outgroup lineage (data not shown). The similar evolutionary distances between the $\alpha$ - and $\beta$-subunits from the three different organisms $(3.02,2.98$ and 2.70 for $A$. fulgidus, D. vulgaris and $\mathrm{Chr}$. vinosum, respectively; Fig. $4 \mathrm{~b}$ ) further suggest similar evolution rates for sulfite reductase in these organisms (Woese, 1987). Hence, the evolutionary distances between the subunits from Chr. vinosum and those from the two other prokaryotes are not overestimated by the differences in amino acid sequence (Iwabe et al., 1989).

\section{Conclusions}

The phylogenetic analysis presented in this study allows general proposals about the evolution of dissimilatory sulfur metabolism to be made. The divergence into the oxidative and the reductive mode of dissimilatory sulfur metabolism was a protogenotic event. In the course of evolution, the set of enzymes optimized for chemotrophic sulfur oxidation was challenged in turn by the evolution of phototrophy (Nisbet et al., 1995). Thus, dissimilatory sirohaem sulfite reductases and APS reductases in anoxygenic phototrophic bacteria predate the evolution of the photosynthetic apparatus. Following this view of early evolution, the single report of a dissimilatory sirohaem sulfite reductase in the Chromatiaceae, that is in Chr. vinosum, as well as the absence of APS reductases in the Rhodospirillaceae, Ectothiorhodospiraceae and some species of the Chromatiaceae, reflect the decreasing significance of these enzymes for the contemporary mode of anoxygenic phototrophy. The very recent observation that APS reductase is not an essential enzyme for photolithoautotrophic growth of Chr. vinosum (Dahl, 1996) is consistent with this view. It is tempting to assume that this holds true for other anoxygenic phototrophic bacteria possessing an APS reductase (such as the Chlorobiaceae). Experiments analogous to those performed by Dahl (1996) will help to clarify the significance of APS reductase in other phototrophs. Sequencing of the structural genes for sirohaem sulfite reductases 
and APS reductases, especially from chemotrophic sulfur oxidizers, will resolve whether this hypothesized scenario matches the actual course of evolution.

\section{ACKNOWLEDGEMENTS}

We thank Markus Walbröl (this laboratory) for the donation of chromosomal DNA from A. fulgidus. Cell paste from $D$. gigas was kindly provided by Ulrike Kappler (this laboratory). This work was supported by the Deutsche Forschungsgemeinschaft ( $\operatorname{Tr} 133 / 23$ and $\mathrm{Da} 351 / 1)$ and the Fonds der Chemischen Industrie (HGT). We are indebted to Petra Peters for critically reviewing the manuscript.

\section{REFERENCES}

Altschul, S. F., Gish, W., Miller, W., Myers, E. W. \& Lipman, D. J. (1990). Basic local alignment search tool. J Mol Biol 215, 403-410.

Ausubel, F. A., Brent, R., Kingston, R. E., Moore, D. D., Seidman, J. G., Smith, J.A. \& Struhl, K. (1996). Current Protocols in Molecular Biology. New York: John Wiley.

Bairoch, A. (1992). PROSITE: a dictionary of sites and patterns in proteins. Nucleic Acids Res 20, 2013-2018.

Baldensperger, J. \& Garcia, J.-L. (1975). Reduction of oxidized inorganic nitrogen compounds by a new strain of Thiobacillus denitrificans. Arch Microbiol 103, 31-36.

Bazaral, M. \& Helinski, D. R. (1968). Circular DNA forms of colicinogenic factors E1, E2 and E3 from Escherichia coli. J Mol Biol 36, 185-194.

Benachenhou-Lahfa, N., Forterre, P. \& Labedan, B. (1993). Evolution of glutamate dehydrogenase genes: evidence for two paralogous protein families and unusual branching patterns of the archaebacteria in the universal tree of life. $J \mathrm{Mol} \mathrm{Biol} \mathrm{36,}$ 335-346.

Benner, S. A. \& Ellington, A. D. (1990). 'Progenote' or 'protogenote'? Science 248, 943-944.

Benner, S. A., Ellington, A. D. \& Tauer, A. (1989). Modern metabolism as a palimpsest of the RNA world. Proc Natl Acad Sci USA 86, 7054-7058.

Bowen, T. J., Happold, F. C. \& Taylor, B. F. (1966). Studies on adenosine- 5 -phosphosulphate reductase from Thiobacillus denitrificans. Biochim Biophys Acta 118, 566-576.

Brune, D. C. (1989). Sulfur oxidation by phototrophic bacteria. Biochim Biophys Acta 975, 189-221.

Campbell, W. H. \& Kinghorn, J. R. (1990). Functional domains of assimilatory nitrate reductases and nitrite reductases. Trends Biochem Sci 15, 315-319.

Chou, Q., Russell, M., Birch, D. E., Raymond, J. \& Bloch, W. (1992). Prevention of pre-PCR mis-priming and primer dimerization improves low-copy-number amplification. Nucleic Acids Res 20, 1717-1723.

Cohan, F. M. (1996). The role of genetic exchange in bacterial evolution. ASM News 62, 631-636.

Crane, B. R., Siegel, L. M. \& Getzoff, E. D. (1995). Sulfite reductase structure at $1.6 \AA$ : evolution and catalysis for reduction of inorganic anions. Science 270, 59-67.

Dahl, C. (1996). Insertional gene inactivation in a phototrophic sulphur bacterium: APS-reductase-deficient mutants of Chromatium vinosum. Microbiology 142, 3363-3372.

Dahl, C., Koch, H. G., Keuken, O. \& Truper, H. G. (1990). Purification and characterization of ATP sulfurylase from the extremely thermophilic archaebacterial sulfate reducer, Archaeoglobus fulgidus. FEMS Microbiol Lett 67, 27-32.

Dahl, C., Kredich, N. M., Deutzmann, R. \& Truper, H. G. (1993). Dissimilatory sulphite reductase from Archaeoglobus fulgidus: physico-chemical properties of the enzyme and cloning, sequencing and analysis of the reductase genes. J Gen Microbiol 139, 1817-1828.

Dayhoff, M. O. (1978). Atlas of Protein Sequence and Structure. Washington, DC: National Biomedical Research Foundation.

Diaz-Lazcoz, Y., Henaut, A., Vigier, P. \& Risler, J.-L. (1995). Differential codon usage for conserved amino acids : evidence that the serine codons TCN were primordial. J Mol Biol 250, 123-127.

Doolittle, R. F. (1994). Convergent evolution: the need to be explicit. Trends Biochem Sci 19, 15-18.

Fauque, G., LeGall, J. \& Barton, L. (1991). Sulfate-reducing and sulfur-reducing bacteria. In Variations in Autotrophic Life, pp. 271-337. Edited by J. M. Shively \& L. Barton. New York: Academic Press.

Felsenstein, J. (1993). PHYLIP (Phylogeny Inference Package) version 3.5c. ftp.bio.indiana.edu/molbio/evolve

Fischer, U. (1989). Enzymatic steps and dissimilatory sulfur metabolism by whole cells of anoxyphotobacteria. In Biogenic Sulfur in the Environment, pp. 262-279. Edited by E. S. Saltzman \& W. J. Cooper. Washington, DC: American Chemical Society. Fitch, W. M. \& Margoliash, E. (1967). Construction of phylogenetic trees. Science 155, 279-284.

Geourjon, C. \& Deleage, G. (1995). sopMA : significant improvements in protein secondary structure prediction by prediction from multiple alignments. Comput Appl Biosci 11, 681-684.

Gish, W. \& States, D. (1993). Identification of protein coding regions by database similarity search. Nat Genet 3, 266-272.

Gogarten, J. P. (1994). Which is the most conserved group of proteins? Homology-orthology, paralogy, xenology, and the fusion of independent lineages. J Mol Biol 39, 541-543.

Hatchikian, E. C. (1994). Desulfofuscidin : dissimilatory, high-spin sulfite reductase of thermophilic, sulfate-reducing bacteria. Methods Enzymol 243, 276-295.

Henikoff, S. (1984). Unidirectional digestion with exonuclease III creates targeted breakpoints for DNA sequencing. Gene 28, 351-359.

Henikoff, S. \& Henikoff, J. G. (1992). Amino acid substitution matrices from protein blocks. Proc Natl Acad Sci USA 89, 10915-10919.

Henikoff, S. \& Henikoff, J. G. (1994). Protein family classification based on searching a database of blocks. Genomics 19, 97-107.

Hipp, W. M. (1996). The Red Book Bulletin. Current Protocols in Molecular Biology, suppl. 3, units 2·9-2·10. Edited by F. A. Ausubel, R. Brent, R. E. Kingston, D. D. Moore, J. G. Seidman, J. A. Smith \& K. Struhl. New York: John Wiley.

Imhoff, J. F. (1992). The family Ectothiorhodospiraceae. In The Prokaryotes, 2nd edn, pp. 3222-3229. Edited by A. Balows, H. G. Trüper, M. Dworkin, W. Harder \& K.-H. Schleifer. New York: Springer.

Imhoff, J. F. \& Truper, H. G. (1992). The genus Rhodospirillum and related genera. In The Prokaryotes, 2nd edn, pp. 2141-2155. Edited by A. Balows, H. G. Trüper, M. Dworkin, W. Harder \& K.-H. Schleifer. New York: Springer.

Iwabe, N., Kuma, K.-I., Hasegawa, M., Osawa, S. \& Miyata, T. (1989). Evolutionary relationship of archaebacteria, eubacteria, and eukaryotes inferred from phylogenetic trees of duplicated genes. Proc Natl Acad Sci USA 86, 9355-9359. 
Iwasaki, T., Wakagi, T., Isogai, Y., Tanaka, K., lizuka, T. \& Oshima, T. (1994). Functional and evolutionary implications of a [3Fe-4S] cluster of the dicluster-type ferredoxin from the thermoacidophilic archaeon, Sulfolobus sp. strain 7. J Biol Chem 269, 29444-29450.

Karkhoff-Schweizer, R. R., Huber, D. P. W. \& Voordouw, G. (1995). Conservation of the genes for dissimilatory sulfite reductase from Desulfovibrio vulgaris and Archaeoglobus fulgidus allows their detection by PCR. Appl Environ Microbiol 61, 290-296.

Kirchhoff, J. \& Truper, H. G. (1974). Adenylylsulfate reductase of Chlorobium limicola. Arch Microbiol 100, 115-120.

Kretz, K., Callen, W. \& Hedden, V. (1994). Cycle sequencing. PCR Methods Appl 3, S107-S112.

Kumar, S. (1996). PHYLTEST: a program for testing phylogenetic hypothesis, version 2.0. imeg@psuvm.psu.edu

Lampreia, J., Moura, I., Teixeira, M., Peck, H. D., Jr, LeGall, J., Huynh, B. H. \& Moura, J. J. G. (1990). The active centers of adenylylsulfate reductase from Desulfovibrio gigas. Eur $J$ Biochem 188, 653-664.

Lampreia, J., Fauque, G., Speich, N., Dahl, C., Moura, I., Truper, H. G. \& Moura, J. J. G. (1991). Spectroscopic studies on APS reductase isolated from the hyperthermophilic sulfate-reducing archaebacterium Archaeoglobus fulgidus. Biochem Biophys Res Commun 181, 342-347.

Lampreia, J., Pereira, A. S. \& Moura, J. J. G. (1994). Adenylylsulfate reductase from sulfate-reducing bacteria. Methods Enzymol 243, 241-260.

Lawrence, C. E., Altschul, S. F., Boguski, M. S., Liu, J. S., Neuwald, A. F. \& Wootton, J. C. (1993). Detecting subtle sequence signals: a Gibbs sampling strategy for multiple alignment. Science 262, 208-214.

Lion, T. \& Haas, O. A. (1990). Nonradioactive labeling of probe with digoxigenin by polymerase chain reaction. Anal Biochem 188, 335-337.

Lockhart, P. J., Steel, M. A. \& Larkum, A. W. D. (1996). Gene duplication and the evolution of photosynthetic reaction center proteins. FEBS Lett 385, 193-196.

Mehta, P. K., Heringa, J. \& Argos, P. (1995). A simple and fast approach to prediction of protein secondary structure from multiply aligned sequences with accuracy above $70 \%$. Protein $S c i$ 4, 2517-2525.

Miller, J. H. (1972). Experiments in Molecular Genetics. Cold Spring Harbor, NY: Cold Spring Harbor Laboratory.

Molitor, M. (1966). Molekularbiologische und physikochemische Charakterisierung der dissimilatorischen Sulfitreduktasen aus Pyrobaculum islandicum und Desulfovibrio simplex. PhD thesis, University of Bonn.

Moodie, S. L., Mitchell, J. B. O. \& Thornton, J. M. (1996). Protein recognition of adenylate: an example of a fuzzy recognition template. J Mol Biol 263, 486-500.

Nakamura, K., Yamaki, M., Sarada, M., Nakayama, S., Vibat, C. R. T., Gennis, R. B., Nakayashiki, T., Inokuchi, H., Kojima, S. \& Kita, K. (1996). Two hydrophobic subunits are essential for the heme $b$ ligation and functional assembly of complex II (succinateubiquinone oxidoreductase) from Escherichia coli. J Biol Chem 271, 521-527.

Neutzling, O., Pfleiderer, C. \& Truper, H. G. (1985). Dissimilatory sulphur metabolism in phototrophic 'non-sulphur' bacteria. J Gen Microbiol 131, 791-798.

Nisbet, E. G., Cann, J. R. \& van Dover, C. L. (1995). Origins of photosynthesis. Nature 373, 479-480.
Odom, J. M., Jessie, K., Knodel, E. \& Emptage, M. (1991). Immunological cross-reactivities of adenosine- 5 -phosphosulfate reductases from sulfate-reducing and sulfide-oxidizing bacteria. Appl Environ Microbiol 57, 727-733.

Olsen, G. J., Woese, C. R. \& Overbeek, R. (1994). The winds of (evolutionary) change: breathing new life into microbiology. J Bacteriol 176, 1-6.

Osawa, S., Jukes, T. H., Watanabe, K. \& Muto, A. (1992). Recent evidence for evolution of the genetic code. Microbiol Rev 56, 229-264.

Ostrowski, J., Wu, J.-Y., Rueger, D. C., Miller, B. E., Siegel, L. M. \& Kredich, N. M. (1989). Characterization of the cysJIH regions of Salmonella typhimurium and Escherichia coli B. J Biol Chem 264, 15726-15737.

Pfennig, N. \& Truper, H. G. (1992). The family Chromatiaceae. In The Prokaryotes, 2nd edn, pp. 3200-3221. Edited by A. Balows, H. G. Trüper, M. Dworkin, W. Harder \& K.-H. Schleifer. New York: Springer.

Richardson, J. P. (1993). Transcription termination. Crit Rev Biochem Mol Biol 1, 1-30.

Robinson, K. M. \& Lemire, B. D. (1996). Covalent attachment of FAD to the yeast succinate dehydrogenase flavoprotein requires import into mitochondria, presequence removal, and folding. J Biol Chem 271, 4055-4060.

Saitou, N. \& Nel, M. (1987). The neighbor-joining method: a new method for reconstructing phylogenetic trees. Mol Biol Evol 4, 406-425.

Sambrook, J., Fritsch, E. F. \& Maniatis, T. (1989). Molecular Cloning: a Laboratory Manual, 2nd edn. Cold Spring Harbor, NY: Cold Spring Harbor Laboratory.

Schedel, M. \& Truper, H. G. (1979). Purification of Thiobacillus denitrificans siroheme sulfite reductase and investigation of some molecular and catalytic properties. Biochim Biophys Acta 568, $454-467$.

Schedel, M., Vanselow, M. \& Truper, H. G. (1979). Siroheme sulfite reductase isolated from Chromatium vinosum. Purification and investigation of some of its molecular and catalytic properties. Arch Microbiol 121, 29-36.

Schidlowski, M. (1986). Evolution of the early sulphur cycle. In Proceedings of the International Meeting on Geochemistry of the Earth Surface and Processes of Mineral Formation, Granada, Spain, pp. 29-49. Edited by R. Rodriguez-Clemente \& Y. Tardy. Madrid: Consejo Superior de Investigaciones Cientificas.

Schroder, I., Gunsalus, R. P., Ackrell, B. A. C., Cochran, B. \& Cecchini, G. (1991). Identification of active site residues of Escherichia coli fumarate reductase by site-directed mutagenesis. $J$ Biol Chem 266, 13572-13579.

Schuler, G. D., Altschul, S. F. \& Lipman, D. J. (1991). A workbench for multiple alignment construction and analysis. Proteins Struct Funct Genet 9, 180-190.

Schwenn, J. D. \& Biere, M. (1979). APS-reductase activity in the chromatophores of Chromatium vinosum strain D. FEMS Microbiol Lett 6, 19-22.

Skyring, G. W. \& Donnelly, T. H. (1982). Precambrian sulfur isotopes and a possible role for sulfite in the evolution of biological sulfate reduction. Precambrian Res 17, 41-61.

Speich, N. \& Truper, H. G. (1988). Adenylylsulphate reductase in a dissimilatory sulphate-reducing archaebacterium. J Gen Microbiol 134, 1419-1425.

Speich, N., Dahl, C., Heisig, P., Klein, A., Lottspeich, F., Stetter, K. O. \& Truper, H. G. (1994). Adenylylsulphate reductase from the sulphate-reducing archaeon Archaeoglobus fulgidus : cloning and 
characterization of the genes and comparison of the enzyme with other iron-sulphur flavoproteins. Microbiology 140, 1273-1284.

Takakuwa, S. (1992). Biochemical aspects of microbial oxidation of inorganic sulphur compounds. In Organic Sulfur Chemistry: Biochemical Aspects, pp. 1-43. Edited by S. Oae \& T. Okuyama. Boca Raton, FL: CRC Press.

Takezaki, N., Rzhetsky, A. \& Nei, M. (1995). Phylogenetic test of the molecular clock and linearized trees. Mol Biol Evol 12, 823-833.

Thauer, R. K. (1989). Energy metabolism of sulfate-reducing bacteria. In Autotrophic Bacteria, pp. 397-413. Edited by H. G. Schlegel \& B. Bowien. Madison, WI: Science Tech Publishers.

Truper, H. G. (1994). Taxonomic notes: names for the higher taxa and their impact on the code of nomenclature of bacteria. Int $J$ Syst Bacteriol 44, 368-369.

Truper, H. G. \& Fischer, U. (1982). Anaerobic oxidation of sulfur compounds as electron donors for bacterial photosynthesis. Philos Trans R Soc Lond B Biol Sci 298, 529-542.
Verhagen, M. F. J. M., Kooter, I. M., Wolbert, R. B. G. \& Hagen, W. R. (1994). On the iron-sulfur cluster of adenosine phosphosulfate reductase from Desulfovibrio vulgaris (Hildenborough). Eur J Biochem 221, 831-837.

Wächtershauser, G. (1988). Pyrite formation, the first energy source for life: a hypothesis. Syst Appl Microbiol 10, 207-210.

West, M. W. \& Hecht, M. H. (1995). Binary patterning of polar and nonpolar amino acids in the sequences and structures of native proteins. Protein Sci 4, 2032-2039.

Wierenga, R. K., Terpstra, P. \& Hol, W. G. J. (1986). Prediction of the occurrence of the ADP-binding beta-alpha-beta-fold in proteins, using an amino acid sequence fingerprint. $J \mathrm{Mol}$ Biol 187, 101-107.

Woese, C. R. (1987). Bacterial evolution. Microbiol Rev 51, 221-271.

Received 3 February 1997; revised 22 May 1997; accepted 27 May 1997. 